\title{
Aggregate demand, functional finance, and secular stagnation
}

\author{
Peter Skott* \\ University of Massachusetts Amherst, USA and Aalborg University, Denmark
}

This paper makes three main points. Fiscal policy, first, may be needed in the long run to maintain full employment and avoid secular stagnation. If fiscal policy is used in this way, second, the long-run debt ratio depends (i) inversely on the rate of growth, (ii) inversely on government consumption, and (iii) directly on the degree of inequality. The analysis, third, suggests that policies and policy debates have been misguided. The recent rediscovery of 'secular stagnation' by Summers and others should be welcomed, but the suggested theoretical redirection is unclear and does not go far enough.

Keywords: functional finance, zero lower bound, liquidity trap, fiscal policy, secular stagnation, austerity, public debt

JEL codes: $E 62, E 22$

\section{INTRODUCTION}

This paper makes three main points. Fiscal policy, first, may be needed in the long run to maintain full employment and avoid secular stagnation. If fiscal policy is used in this way, second, the long-run debt ratio depends (i) inversely on the rate of growth, (ii) inversely on government consumption, and (iii) directly on the degree of inequality. The analysis, third, suggests that policies and policy debates have been misguided. The recent rediscovery of 'secular stagnation' by Summers and others should be welcomed, but the suggested theoretical redirection is unclear and does not go far enough.

Throughout the paper, the analysis will be confined to closed economies, and it will be assumed that public debt is denominated in a currency that is controlled by the central bank. In economies of this kind the government can never be forced to default on its debt obligations. The situation is fundamentally different for an open economy with debt denominated in foreign currency. The importance of this simple distinction, surprisingly, does not seem to be universally recognized. Collard et al. (2015), for instance, calculate 'sustainable' public debt ratios using the same criteria for the US and for Greece; Reinhart/ Rogoff (2010) make no distinctions between countries based on the denomination of the public debt; the popular press has been full of references to Greece as a cautionary tale for what could happen to the US if public debt is not reined in.

The closed economy assumption means that the analysis is not directly applicable to a country like Greece. But indirectly the analysis is highly relevant. Policy analysis should not focus narrowly on the options for Greece, taking as given the international environment in which it operates. An analysis of this kind might show austerity in some

* Email: pskott@econs.umass.edu. The paper draws on material from Ryoo/Skott (2013; 2015), Skott/Ryoo (2014; 2015), and Skott (2016). 
form to be the only viable option. The same conclusion might follow from the analysis of, say, Portugal or Ireland, each seen in isolation and taking their international environment as given. But austerity policies cannot be justified in this way for the eurozone as a whole. Small open economy models are intrinsically 'partial' and subject to the same fallacy of composition problems as other partial models, including the quintessential Keynesian examples. ${ }^{1}$ The eurozone controls its own currency and, less importantly, most of the international trade of the eurozone countries is with other countries within the zone. Models of a closed economy with debt in its own currency can provide essential tools for an analysis of what could and should be done in the eurozone as a whole.

The analysis is subject to a second domain assumption. The focus is on 'mature economies.' Post-Keynesian models often consider a dual economy with a perfectly elastic supply of labor. These models may be relevant for economies with large amounts of (open or hidden) un- and underemployment in which the growth rate can be determined without any reference to the labor market. In a mature economy, by contrast, the labor supply is not perfectly elastic. For simplicity I shall take the full-employment growth rate as exogenously given, but the analysis could be extended to allow endogeneity in the growth rate. ${ }^{2}$ For present purposes the important distinction between dual and mature economies is the existence in the latter of a welldefined target value for the full-employment growth rate. This mature-economy assumption, in my view, provides a better starting point for the analysis of advanced economies like the US, Japan, or most of Europe than the alternative dual economy assumption.

Section 2 presents some simple algebra. The algebra leaves a degree of freedom, and theory is needed to close the model. Section 3 discusses a mainstream closure, and Section 4 turns to a Keynesian, functional-finance perspective. Section 5 outlines some implications of functional finance. Section 6 discusses secular stagnation. I briefly consider the Japanese case - which has figured prominently in these discussions - before commenting on the recent rediscovery by Summers and others of secular stagnation. Section 7 concludes.

\section{SOME SIMPLE ALGEBRA}

The nature of the long-run demand issue can be highlighted by a few, well-known equations. The first equation is the equilibrium condition for the goods market in a closed economy,

$$
\frac{Y}{K}=\frac{C}{K}+\frac{I}{K}+\frac{G}{K}
$$

The familiar $Y=C+I+G$ equation has been divided through by the capital stock; this is just a convenient normalization when dealing with long-run growth.

The ratio of government consumption to the capital stock is taken to be exogenous,

$$
\frac{G}{K}=\gamma
$$

The value of the government consumption ratio is contentious. How much should we spend on public education or public health care, for instance? For present purposes,

1. An individual worker may be able to find work by accepting a low wage just as an individual household may raise its saving by reducing consumption. But this does not imply that reductions in the money wages for all workers will also raise aggregate employment or that a reduction in aggregate consumption raises aggregate saving.

2. The natural growth rate - the growth in the labor supply in efficiency units - could depend on the employment rate (for example, Flaschel/Skott 2006). 
however, debates on the appropriate size of the public sector are largely irrelevant. The main questions that I want to explore relate to the principle of functional finance, and these questions can be addressed independently of the precise level of the government consumption ratio. ${ }^{3}$

The third equation represents straightforward accounting. In order to maintain fullemployment growth and a constant output capital ratio, the ratio of gross investment to the capital stock must be equal to the sum of the growth rate of the labor supply $(n)$ and the rate of depreciation $(\delta)$ :

$$
\frac{I}{K}=n+\delta
$$

By definition the output-capital ratio is constant in steady growth, but the steadygrowth value may be endogenous. Mainstream theory typically assumes a smooth production function with substitutability between capital and labor. This assumption may be heroic, but it is also restrictive to ignore the choice of technique. Hence I shall allow for a dependence of the output-capital ratio $(\sigma)$ on the cost of finance and, for simplicity, the cost of finance is taken to be determined by the real rate of interest. ${ }^{4}$ Formally,

$$
\sigma=\frac{Y}{K}=f(r)
$$

Equation (4) reflects two assumptions: the possible influence of the interest rate on the choice of technique and, second, the assumption that the utilization of capital is at the desired rate in steady growth. ${ }^{5}$

Combining equations (1)-(4), the condition for steady growth with full employment can be written as:

$$
\sigma-\frac{C}{K}=f(r)-\frac{C}{K}=\gamma+n+\delta .
$$

The variables on the right-hand side of (5) are exogenous, and any adjustment has to come through either the output-capital ratio (the real rate of interest) or the consumption-capital ratio. The question is, will these adjustments happen automatically or is there a need for active policy? If the adjustment occurs automatically via changes in interest rates and the output-capital ratio, one can ask whether these changes lead to a capital intensity that is 'socially optimal' in some sense. If the adjustment does not come via the choice of technique, the consumption ratio must do the adjusting, and we need to examine the determination of this ratio. In particular, is policy intervention needed to affect the consumption ratio, and if so, what kind of policy should be used?

Before proceeding, it may be useful to consider some possible Kaleckian and Sraffian objections to the way I am posing the questions. Kaleckians may take issue with the

3. There is undoubtedly a positive correlation between support for public consumption and support for an active fiscal policy along the lines of functional finance, but that is a different issue.

4. There are two factor prices: the cost of finance and the wage. The cost of finance is taken to be fully determined by the interest rate; the real wage is determined by the mark-up and the productivity of labor. Combining the first-order condition from the choice of technique with a mark-updetermined real wage, the choice of technique can be expressed as a function of $r$. See Skott (1989: ch. 5) or Skott/Ryoo (2015) for details.

5. The specification allows for a possible dependence of the desired utilization rate on the interest rate (Skott 1989; Ryoo/Skott 2015). 
treatment of the utilization rate of capital; Sraffians may question the treatment of the choice of technique.

Post-Keynesian models typically take the production function to be of the Leontief type: there is no choice of technique. This assumption does not necessarily mean that there is no endogeneity in the output-capital ratio in these models. In fact, Kaleckian models require accommodating variations in the utilization rate of capital, not just in the short run (which is uncontroversial) but also across different steady growth paths. The large long-run variations envisaged by these models are at odds with the evidence and also, I believe, hard to defend behaviorally. ${ }^{6}$ The analysis in this paper therefore assumes that the utilization rate will be equal to the desired rate in steady growth. This assumption is in line with both classical and Harrodian approaches to economic growth. ${ }^{7}$

Objections to my treatment of the choice of technique may point to the capital controversy. The controversy highlighted the difficulties of constructing an aggregate production function and demonstrated, in particular, how reswitching and capital reversing may undermine economic theories that rely on movements along a smooth production function. But these insights from the capital controversy do not imply that only one technique is available; nor do they invalidate the influence of the cost of finance on the choice of technique.

The key question is not the existence of a choice of technique; it is whether the output-capital ratio will adjust automatically to ensure continuous full employment. It is this automatic adjustment in Solow-type models that is questionable. ${ }^{8}$ It is questionable for several reasons. The scope for capital-labor substitution is limited in the short run; neighboring techniques in terms of capital intensity may differ widely in terms of the specific, disaggregated capital goods that they use; a fall in the cost of finance may lead to a 'perverse' reduction in the aggregate capital intensity (the famous case of capital reversing). But perhaps most importantly, when firms choose the capital intensity of the productive capacity generated by new investment, the choice is guided by relative input prices. If these relative input prices fail to clear the labor market, the choice of technique will be determined by the wrong prices. ${ }^{\text {? }}$

Returning to the choice of technique as described by equation (4), a mainstream story with smooth and well-behaved substitution has $f^{\prime}>0$; the capital controversy raised questions about the smoothness of the $f$-function and showed that even if the $f$-function is differentiable, we may have $f^{\prime}<0$; a Leontief production function without any choice of technique corresponds to the special case with $f^{\prime} \equiv 0$. The differences between the three cases can be critical for the adjustment process towards a steady growth path. As a characterization of steady growth paths, however, the general expression in (4) is consistent with all three cases.

6. The objections are spelled out in greater detail in Skott (2012) and Skott/Zipperer (2012); a Kaleckian position is presented, inter alia, by Lavoie (1995), Dutt (1997), Dallery/van Treeck (2011), and Hein et al. (2012).

7. Harrodian instability issues will not be considered in this paper. The paper examines policy requirements for sustaining aggregate demand at the full-employment trajectory, assuming that the capital stock grows at the natural rate. Franke (2015) and Ryoo/Skott (2015) analyse economic policy in economies with Harrodian instability.

8. In Joan Robinson's (1974: 9) words: 'The long wrangle about "measuring capital" has been a great deal of fuss over a secondary question. The real source of trouble is the confusion between comparisons of equilibrium positions and the history of a process of accumulation.'

9. The lack of stability of full employment, not a rejection of the existence of a full employment equilibrium, was the key message of Keynes's analysis in The General Theory (1936); the lack of stability in turn was associated with a lack of automatic adjustments in factor prices (ibid.: ch. 19). 


\section{MAINSTREAM ANSWERS}

The determination of the output-capital ratio and the consumption ratio differs across theories. Mainstream macroeconomics suggests that aggregate demand will adjust automatically and that the equilibrium condition (5) will be met in the long run. The traditional Solow model relies exclusively on variations in the output-capital ratio to ensure that the condition (5) will be satisfied. DSGE models with Ramsey optimization introduce an additional adjustment mechanism.

In a Ramsey setting, the growth in per capita consumption satisfies the Euler condition

$$
\hat{c}=\frac{1}{\theta}(r-\rho),
$$

where $\rho$ is the representative household's discount rate and $\theta$ the intertemporal elasticity of substitution; $r$ is the real rate of interest and $c$ per capita consumption; a hat over a variable denotes a rate of growth $(\hat{x}=\dot{x} / x=(d x / d t) / x)$. The growth rate of per capita consumption is constant in steady growth, and equation (6) implies the existence of a well-defined 'natural rate of interest':

$$
r=\rho+\theta \alpha
$$

where $\alpha$ is the rate of labor saving technical change. Given this unique 'natural rate of interest,' equation (4) determines the capital intensity. Using the representative household's utility function as the welfare criterion, moreover, the Ramsey model implies that the growth path - including the capital intensity - will be optimal in the absence of externalities or other market imperfections. ${ }^{10}$ Unlike in the Solow model with a fixed saving rate, there is no danger of 'dynamic inconsistency'; high saving rates will never take the capital intensity to a level above the 'golden rule.' In fact variations in capital intensity are not even needed to ensure full-employment growth: the saving rate is an endogenous variable, and if $\sigma$ is exogenously given (the Leontief case), the saving rate (and thus $C / K$ ) will do all of the adjustment in equation (5).

In short, dynamic stochastic general equilibrium (DSGE) models based on Ramsey optimization give a clear answer. Short-run problems associated with nominal stickiness may call for an active monetary policy, but market adjustments in real wages and interest rates in combination with the endogeneity of the saving rate serve to maintain full employment in the medium and long run. There is no need for either countercyclical or long-run fiscal policy. This is fortunate since Ricardian equivalence makes fiscal policy ineffectual in this setting: far-sighted households adjust their saving in response to changes in taxes. The main concern of fiscal policy becomes to minimize tax distortions. If revenue cannot be raised exclusively through lump-sum taxes and the costs of distortion are convex, this objective translates into tax-smoothing (Barro 1979).

The DSGE/Ramsey results have dominated mainstream thinking. They are not robust, however. Relax the model by introducing finite lives, as in overlapping generations (OLG) models without intergenerational altruism, and the optimality of the market outcome disappears. Even with perfect optimization and continuous full employment, OLG models can produce dynamic inefficiency: the capital intensity may be so high (and the return on

10. Although widely praised as 'correct' (Blanchard 2008: 9) or 'natural' (Woodford 2003: 12), there is nothing correct or natural about this approach. The use of the representative agent's utility function as the social welfare function implies a systematic and intrinsic bias in favor of the rich (Skott/Davis 2013). 
capital so low) that all generations could be made better off by a reduction in saving. More generally, there is no presumption that market solutions will be socially optimal in these models.

The definition of social welfare raises a host of issues but consider a simple case without any intra-generational inequality. Intergenerational distribution then becomes the only distributional issue, and the social discount rate will be central to the determination of a socially optimal trajectory. In the absence of discounting, the optimal trajectory maximizes consumption per capita in steady growth (the golden rule); if the social welfare function calls for discounting future consumption, the steady-growth value of the capital intensity will be below the golden-rule level. Conditional on the normative choice of a discount rate, let $\sigma^{*}$ and $r^{*}$ be the socially optimal capital intensity and the associated interest rate. Except by a fluke, these values will be inconsistent with market clearing in a neoclassical OLG model: the value of $C / K\left(\right.$ at $\sigma=\sigma^{*}, r=r^{*}$ ) will not clear the goods market at full employment:

$$
\frac{C}{K}>\sigma^{*}-\gamma-(n+\delta) .
$$

The finite horizons also bring a solution to the problem that they create: the ineffectiveness of fiscal policy disappears when households have finite horizons, even if one retains all other assumptions of rational behavior and perfect foresight. Future taxes will be paid by different taxpayers, and there is no Ricardian equivalence in the OLG model. Changes in current taxes therefore influence current consumption, and fiscal policy can be used to maintain full employment and an optimal capital intensity. The flipside of these results is that fiscal policy affects the interest rate and the choice of technique. Putting it differently, unlike in models with Ramsey optimization, the 'natural rate of interest' - the interest rate associated with full employment - cannot be defined independently of fiscal policy.

There is nothing new and radical about these propositions. Diamond (1965) derived many of them formally for a neoclassical OLG model; see also Skott/Ryoo (2014; 2015).

\section{FUNCTIONAL FINANCE}

OLG models have many failings from a Keynesian perspective, but very similar conclusions can be reached using more traditional Keynesian models.

Twenty-two years before the Diamond model, Lerner (1943) had discussed the principle of 'functional finance.' Fiscal policy, he argued, is an essential instrument of Keynesian policy, and it should be used 'with an eye only to the results of these actions on the economy and not to any established traditional doctrine about what is sound or unsound' (ibid.: 39, emphasis in original). According to functional finance, there is nothing virtuous about balancing the government budget over any particular period. The public debt, likewise, is of no importance in itself. Households may need to balance their budgets, but governments are under no such compulsion, and doctrines of 'sound finance' are based on a false analogy.

Lerner spells out the implications of functional finance. ${ }^{11}$ Functional finance, he argues,

prescribes, first, the adjustment of total spending (by everybody in the economy, including the government) in order to eliminate both unemployment and inflation ...; second, the adjustment

11. A large Keynesian literature takes positions that are similar to functional finance (even if not always directly inspired by Lerner); examples include Schlicht (2006), Godley/Lavoie (2007), Arestis/Sawyer (2010), Davidson (2010), Palley (2010), and Nersisyan/Wray (2010). 
of public holdings of money and of government bonds, by government borrowing or debt repayment, in order to achieve the rate of interest which results in the most desirable level of investment; and, third, the printing, hoarding or destruction of money as needed for carrying out the first two parts of the program. (Lerner 1943: 41)

The 'most desirable level of investment' is typically taken as given in the short run, and the extension of Lerner's argument to the analysis of long-run growth may need comment.

The change in the capital stock is given by the difference between investment and depreciation,

$$
\dot{K}=I-\delta K
$$

A trajectory of desirable levels of investment therefore defines a trajectory of desirable capital stocks. If full employment is being maintained along this trajectory, we also have a trajectory for output. Thus, from a long-run perspective, Lerner's prescriptions for policies that produce full employment and desirable levels of investment can be stated alternatively as prescriptions for policies that produce a trajectory of full employment and desirable output-capital ratios. The output-capital ratio in steady growth is determined by the choice of technique, and we can now use the simple framework in the previous section: Lerner's investment argument translates into the requirement that the steady-growth value of the interest rate satisfy the condition

$$
r=f^{-1}\left(\sigma^{*}\right) .
$$

This requirement pins down the steady-growth value of the real interest rate, and policy-makers must turn to fiscal policy to adjust aggregate demand and maintain full employment. ${ }^{12,13}$ We have taken government consumption as exogenous, but taxes and transfers can be used to affect consumption. ${ }^{14}$

Functional finance holds that intrinsically government deficits and public debt are neither good nor bad. Even from a functional finance perspective, however, the level of debt is not irrelevant. High debt may not be morally wrong, and there may be no risk that the government becomes unable to pay back the debt, but the level of debt can have implications for the distribution of income and for the effectiveness of monetary policy; Taylor rules that are stabilizing for low debt ratios can become destabilizing if the debt ratio exceeds a certain threshold (Ryoo/Skott 2015). Added to this, the possibility that public debt could become 'unsustainable' has been a recurrent theme in policy debates. Thus, it may be interesting to examine the implications of functional finance for the time path of public debt.

The change in public debt is given by

$$
\dot{B}=r B+G-T
$$

12. In the Leontief case, without a choice of technique, the interest rate has no effect on the righthand side of equation (8), and the interest rate can be set to satisfy some other objective (to affect the share of income going to rentiers, for instance). The underlying determinants of $\sigma^{*}$ and $r^{*}$ are irrelevant for the subsequent analysis of the fiscal policy requirements.

13. This determination of the steady-growth value of the interest rate does not preclude short-run variations in the interest rate around its steady-growth value for stabilization purposes (Franke 2015; Ryoo/Skott 2015).

14. The exogeneity of government consumption (and the taxes) is a reasonable assumption for the long run. Variations in government consumption around the exogenous long-run trajectory may be a better tool for short-run stabilization, however (Ryoo/Skott 2015). 
and under functional finance, the policy-makers adjust $T$ to maintain full employment growth. The required adjustments in taxes depend on the precise specification of consumption. For present purposes, I shall simply assume that consumption is a linear function of income and wealth, and that household wealth is the sum of fixed capital and the stock of government bonds. Formally,

$$
C=c(Y+r B-T)+\mu(K+B),
$$

where $T$ and $B$ are taxes and government debt, and the positive parameters $c$ and $\mu$ describe the propensity to consume out of current disposable income and wealth.

As shown in Appendix 1, equations (5), (10), and (9) produce a differential equation for the debt-to-capital ratio, $b=B / K$ :

$$
\dot{b}=\frac{1}{c}\left[(1-c)\left(\sigma^{*}-\gamma\right)-\mu-n-\delta\right]-\left(n+\frac{\mu}{c}\right) b .
$$

The negative feedback from the level of the debt ratio to the change in the debt ratio implies that the stationary solution is stable. The intuition is simple. An increase in public debt raises both private disposable income (for given $T$ ) and private wealth. Both of these effects stimulate consumption, and policy-makers need to raise taxes in order to prevent overheating and inflation.

Stability implies that the debt ratio converges to the stationary solution,

$$
b \rightarrow b^{*}=\frac{(1-c)(\sigma-\gamma)-\mu-n-\delta}{n c+\mu} .
$$

\section{IMPLICATIONS}

\subsection{Growth effects}

It follows from equation (11) that the steady-growth value of the debt ratio depends inversely on the natural growth rate $n$. This implication of the model has direct relevance for the interpretation of observed correlations between debt and growth.

Reinhart/Rogoff (2010: 575) famously argued that debt-to-GDP ratios above 90 percent 'mean levels of growth almost 4 percent lower.' Their evidence turned out to be based on spreadsheet errors and curious weighting procedures (Herndon et al. 2014). The sharp threshold disappears when these errors are corrected, but the data still appear to show a negative correlation between growth and debt. The implications of this correlation are far from obvious. The correlation could be entirely spurious, and if there are causal links, the causation could go either way or both ways.

The evidence from short-run patterns suggests causality from growth to debt (Ash et al. 2015). This result may not be surprising: tax revenues drop when growth falters, leading to rising debt. The more interesting question concerns the links between growth and debt in the long run, and a purely empirical analysis is unlikely to shed much light on this longrun question. The model in Section 4 contributes a theoretical perspective. It shows that fiscal policies that maintain full employment produce a long-run causal link from low growth rates to high debt ratios: low growth leads to high debt. Intuitively, a higher growth rate implies that the share of investment in output must rise and that consumption must be squeezed. This squeeze is achieved by raising taxes, and higher taxes reduce the long-run debt ratio.

The growth rate was taken to be exogenous in Section 4, and causality runs unambiguously from growth to debt. The exogeneity assumption can be challenged, and causality 
could run both ways; the presence of a causal link from growth to debt does not preclude a reverse link from debt to growth. Several mechanisms have been suggested (see, for example, the survey in Elmendorf/Mankiw 1999).

One set of arguments relies on crowding out and an increase in interest rates. The evidence does not, however, show a clear positive relation between the public debt ratio and interest rates. The US has seen large variations in the debt ratio but the correlation with interest rates is, if anything, negative. This lack of support for crowding out is confirmed by more detailed studies. In the words of Engen/Hubbard (2005: 83), 'some economists believe there is a significant, large, positive effect of government debt on interest rates, others interpret the evidence as suggesting that there is no effect on interest rates.'

Distortionary taxation represents another possible source of negative causal effects from debt to economic growth. The broad evidence may not be kind to this hypothesis; the US experienced its highest rates of sustained growth during the high-tax years of the 'golden age.' But leaving aside doubts about the magnitude and relevance of any such effects, the argument faces another problem: an increase in the debt ratio need not be associated with a rise in the tax rate. Both the long-run debt ratio and the long-run tax rate are endogenous variables but, as shown in Appendix 2, the correlation between tax rate and debt can be negative. Shifts in the consumption parameters $c$ and $\mu$, for instance, will produce opposite movements in the long-run values of the debt ratio and the tax rates if $r\left(1-\frac{\gamma}{\sigma}\right)<n$. Thus, if tax rates have negative growth effects, high debt could be beneficial.

\subsection{Austerity}

In the short run, austerity leads to recession, and a fall in income tends to raise the debt-income ratio (Leão 2013). The analysis in Section 4 shows that austerity policies may also be counterproductive on their own terms in the long run (assuming that the aim is to reduce public debt and not just to squeeze the public sector): the debt ratio in equation (11) depends inversely on government consumption $\gamma$.

Schlicht (2006) derives this result for a model that is closely related to the one in Section 4, and the result is quite robust. Ryoo/Skott (2013) show that it holds for a stock-flow consistent model of a corporate economy (an economy in which household wealth takes the form of bonds and stocks rather than direct ownership of fixed capital). Skott/Ryoo (2014; 2015) consider neoclassical and Keynesian OLG models and show that austerity in the form of cuts to social security generate a rising debt ratio. Hysteresis effects in the labor market could reinforce these results. Like the analysis in Section 4, the above papers take the employment trajectory associated with full employment to be independent of short-run fluctuations in output. If austerity policies that cause a recession produce permanent (or very prolonged) negative effects on the future employment trajectory, the paradoxical long-run effects of austerity on debt are magnified (DeLong/ Summers 2012).

\subsection{Income distribution and saving}

The rich, on average, have a higher rate of saving than the poor, and rising inequality tends to reduce the average rate of consumption. A fall in consumption, however, must be offset by fiscal expansion to prevent unemployment. The model in Section 4 did not include income distribution explicitly, but equation (11) can be used to find the derived effects of changes in household behavior on the debt ratio. Not surprisingly, the equation shows that the debt ratio depends inversely on the consumption parameters $c$ and $\mu$. 
The distribution of income is important in its own right, and post-tax inequality can be affected by the structure of taxation. Interestingly, the structure of taxation also influences the debt dynamics. The stability of the debt ratio derives from two feedback effects. An increase in debt raises consumption both via the wealth effect and because of the rise in interest payments associated with an increase in debt. Functional finance calls for an increase in taxes to neutralize this stimulus to aggregate demand. If, as in Section 4, all households have the same consumption rate out of disposable income, the result is a stable income dynamics.

Distribution effects in combination with differential saving rates can weaken the magnitude of the required tax increase following a rise in debt: a small tax increase on workers with a low saving rate may be sufficient to offset the demand effect from interest payments that go to high-saving rentiers. If this happens the increase in debt can lead to a rise in the deficit, and the debt dynamics can become explosive. The remedy is straightforward: use taxes on capital income as the fiscal instrument, instead of taxes on wage income. The same reasoning has another implication. Switching taxes towards capital income and the rich will reduce the long-run debt ratio in the stable case. Indeed, this conclusion was anticipated by Lerner (1943: 49):

if for any reason the government does not wish to see private property grow too much (whether in the form of government bonds or otherwise) it can check this by taxing the rich ... The rich will not reduce their spending significantly ... By this means the debt can be reduced to any desired level and kept there.

\section{SECULAR STAGNATION}

Japan experienced 25 years of miracle growth in the postwar period. GDP per capita grew at an astounding average annual rate of 8.2 percent between 1945 and 1970 . The per capita growth rate dropped to 3.6 percent between 1970 and 1990, and the Japanese economy has stagnated since then. With average per capita growth of only 0.8 percent between 1990 and 2014, Japan has become the poster case for 'secular stagnation,' and policy-makers appear powerless. Interest rates have hit the zero lower bound, and public debt has climbed to about 250 percent of GDP. Simple as it is, the analysis in Sections 4-5 can help make sense of this pattern of growth and stagnation.

The Japanese economy was characterized by large amounts of hidden unemployment and underemployment until the late 1960s. Throughout this period the labor supply to the modern sector was highly elastic, and there was a large potential for technological catch-up. An elastic labor supply and a potential for technological catch-up do not ensure fast growth. In the absence of state intervention - improvements in infrastructure and education along with successful industrial strategies - the economy could have followed a very different, slow-growth trajectory. But the elastic labor supply was important by permitting fast growth, and fast growth (high accumulation rates) allowed the goods market to be in equilibrium, despite high saving rates.

Labor constraints began to appear around 1970 as the economy approached maturity. The growth rates of the previous period exceeded the 'natural rate of growth,' and a decline in the rate of growth was inevitable. But the growth rate dropped below the natural rate. A combination of high saving rates and slow growth produced a structural liquidity trap: 'the proximate problem of the Japanese economy in the 1990s may be one of aggregate demand, but the demand deficiency is structural' (Nakatani/Skott 2007: 307).

With high saving rates, a low natural rate of growth and a reduced accumulation potential, Japan needed other sources of aggregate demand. The financial and real-estate bubble 
of the 1980s alleviated the demand problems for while, but when the bubble burst, the public and foreign sectors would have had to pick up the slack to maintain full employment. Political constraints excluded large and sustained trade surpluses, and political constraints also restrained the fiscal route. The result was limping growth with persistent underperformance, weak labor markets and deflationary tendencies.

Insufficient aggregate demand remains a problem. A more aggressive demand policy is called for, and public debt should be allowed to rise. This does not imply that ever-increasing debt will be required. The structural problems have been loosened somewhat, partly as a result of the rise in debt that has been allowed to take place. The debt may not be as high as it should have been, had the authorities followed a pure functional finance approach, but fiscal deficits and a large debt have boosted demand. Other factors have helped too. Demographic changes and an aging population have contributed to a fall in the saving rate; the household saving rate out of net disposable income has declined steeply from around 20 percent in the mid 1970s to about 2 percent after 2010 .

This broad story of the Japanese economy explains both the rapid growth and the subsequent stagnation within the same general framework. It does this by drawing on both demand and supply side elements. The fundamental change on the supply side was the transition from a dual to a mature economy; this transition and the associated decline in the share of investment in output led to structural demand-side problems.

The supply side appears in most accounts of Japanese stagnation, but typically in a very different way. It is commonly argued that the Japanese economy suffers from structural problems of various kinds and that fundamental reforms are needed. The latest OECD Economic Survey follows this line. There is a need for 'bold structural reforms' to 'improve the business climate' (by, inter alia, 'promoting labor market flexibility' and 'revitalising venture capital investment') (OECD 2015: 5). Fiscal policy also needs to be addressed, and the 'top fiscal priority is reducing government debt' (ibid.). The benefits of these reforms from a pure supply-side perspective - assuming that there were no aggregate demand problems - are not obvious, and some of the OECD recommendations will have strong, adverse effects on the demand side. Fiscal consolidation is the obvious case in point but not the only one. Supply-side reforms that increase inequality will tend to raise the saving rate and reduce aggregate demand. ${ }^{15}$

The demand side has received attention, too. Demand-side explanations have focused on inadequate fiscal and monetary policies in combination with the slowdown of investment following the bubble period in the late 1980s (Krugman 1998). As far as they go, these explanations are in line with the argument in this paper. But until recently at least, aggregate demand problems have been seen as largely transitory, not as reflections of a structural, long-run demand issue. This may be changing with the rediscovery of 'secular stagnation' by Summers and others.

In his presentation at an IMF conference Summers (2013) raised the prospect of secular stagnation, not just for Japan but as a relevant concern for other advanced economies, including the US. ${ }^{16}$ Summers's theoretical analysis was somewhat tentative, but the presentation still caused a stir. Summers (2015a: 61) elaborates on the argument, suggesting that because of 'the zero bound on nominal interest rates' there is 'no guarantee that the

15. A disregard of aggregate demand can be found in many contributions. Rather then reflecting policy responses to weak demand, the Japanese case, according to Obstfeld (2013: 2), 'illustrates how dangerous it can be to tolerate large public debt buildups.'

16. The dangers of secular stagnation have been emphasized by many (post-) Keynesians before Summers's intervention. Examples include Godley (1999), Wray (2000), Skott (2001), and Palley (2002). 
real rate will be low enough for full employment.' Importantly, this state of affairs may not be short-lived since 'equilibrium interest rates may be lower on a sustained basis' (ibid.: 62). He concludes that 'finding ways to increase the demand to spend, no matter how counterintuitive, is likely to be an important part of the way forward' (ibid.: 65). Summers also accepts, however, that 'fiscal policy may not be possible, given that the government cannot indefinitely expand its debt' (Summers 2015b).

Krugman has been making similar points about the need for increased spending in his discussions of liquidity traps and the lessons from Japan (for example, Krugman 2013). Like Summers, he also sees high debt as a problem:

Yes, the United States has a long-run budget problem. Dealing with that problem is going to require, first of all, sharply bending the curve on Medicare costs; without that, nothing works. And second, it's going to require some combination of spending cuts and revenue increases, amounting to at least 3 percent of GDP and probably more, on a permanent basis. (Krugman 2010)

The nature of the long-run debt problem is not explained and there appears to be no recognition that public debt does not need to expand indefinitely. The Summers and Krugman analysis presents a strong contrast to Reinhart-Rogoff claims about dramatic, negative effects of debt on growth. But the break is incomplete.

Part of the problem may stem from the lack of a clear theoretical framework in Summers's analysis. The reference to 'equilibrium interest rates' raises a number of questions. The equilibrium interest rate may be well-defined in DSGE models with Ramsey optimization. But secular stagnation finds no place in these models and fiscal policy is ineffectual. Leaving the DSGE setting, fiscal policy and the size of the public debt influence aggregate demand. But, as argued in Sections 4-5, the output-capital ratio that is required for steady growth with full employment - and thereby the interest rate that is required - will be contingent on the fiscal parameters. Putting it differently, assumptions must be made about fiscal policy and the debt ratio in order for statements about 'equilibrium interest rates' to be meaningful.

Functional finance faces a similar question but approaches it differently: interest rates are chosen to achieve the desirable capital intensity (possibly taking into account other criteria, including income distribution) and contingent on this choice, fiscal policy is adjusted to maintain full employment. The result is an endogenously determined longrun debt ratio.

If there were strong reasons to prefer a particular debt ratio, one could start with a target for the debt ratio and let interest rates and the capital intensity do the adjusting. Assuming that the output-capital ratio (the choice of technique) depends strongly on interest rate, the equilibrium interest rate could be defined as the rate that is consistent with full employment and the target debt ratio. ${ }^{17}$ This may be Summers's implicit assumption. But if it is, the target debt ratio needs to be specified, and it is not obvious that this target should be independent of other parameters that affect aggregate demand. Consider, for instance, a fall in the natural growth rate. An exogenously specified target for the debt ratio would imply that all the adjustment falls on the capital intensity. Assuming a well-behaved production function, the capital intensity would need to rise, even if this were to lead to dynamic inefficiency. Moreover, unlike functional finance, a reliance on adjustments in capital intensity to maintain growth with full employment comes up against all the problems highlighted by the capital controversy.

17. The sensitivity of the choice of technique to changes in interest rates becomes important if one takes this approach. By contrast, functional finance operates equally well with Leontief production function. 


\section{CONCLUSION}

Austerity policies have had devastating consequences for unemployment, poverty, and political instability. Some of the most dramatic examples come from the eurozone, and the analysis in this paper does not apply directly to individual countries in a currency union. But it does apply to the eurozone as whole. The obsession with public debt and sound finance is tragic and unnecessary.

It is disturbing and deeply ironic that the main justification for these policies has come in large part from crude correlations between debt and growth. It is disturbing because simple correlations leave open the question of causation. It is ironic because the advocacy has come from a profession that has been preaching the Lucas critique and the impossibility of informed policy analysis based on mere statistical correlation. ${ }^{18}$ It is doubly ironic because the theoretical orthodoxy that emerged in response to the Lucas critique implies that, as a first approximation, public debt is a non-issue.

Another defense of sound finance comes from calculations that show the 'unsustainability' of large, permanent primary deficits. These calculations are largely silly. There is no point in asking whether this or that arbitrary path of primary deficits is sustainable. Arbitrary paths generally do not produce good results. No Keynesian economist advocates policies of this kind. Fiscal and monetary policies are instruments. They should be designed to maintain (non-inflationary) full employment and a desirable trajectory for investment (and thereby the capital-output ratio). Market forces do not automatically ensure these outcomes and there is need for aggregate demand policy.

The rediscovery of secular stagnation shows a growing recognition that aggregate demand problems need not be short-lived. It remains to be seen whether this recognition will lead mainstream macroeconomics to break with the Lucas inspired research program and move away from models based on optimizing representative households with infinite horizons. As it is, Summers and most other contributors to this literature seem reluctant to make that break. The analysis therefore is left curiously atheoretical with ill-defined notions of 'equilibrium interest rates' as a centerpiece of the argument. The call for measures to increase aggregate demand is in line with functional finance, however, and a functional finance perspective has implications for public debt. In this paper I have highlighted three of them. Low economic growth, first, tends to produce high debt. Reductions in government consumption, second, tend to raise the debt in the long run. Increasing inequality, third, tends to raise the debt. The model in this paper is exceedingly simple, but the same qualitative results can be derived for a range of models.

\section{REFERENCES}

Arestis, P., Sawyer, M. (2010): The return of fiscal policy, in: Journal of Post Keynesian Economics, 32(3), 327-346.

Ash, M., Basu, D., Dube, A. (2015): Public debt and growth: assessing key findings on causality and thresholds, Mimeo, University of Massachusetts Amherst.

Barro, R. (1979): On the determination of the public debt, in: Journal of Political Economy, 87(5), 940-971.

Blanchard, O. (2008): The state of macro, NBER working paper 14259, URL: http://www.nber. org/papers/w14259.

18. See Skott (2014) for a discussion of the Lucas critique (which prompted the move towards these models) and the implications of the critique. 
Collard, F., Habib, M., Rochet, J.-C. (2015): Sovereign debt sustainability in advanced economies, in: Journal of the European Economic Association, 13(3), 381-420.

Dallery, T., van Treeck, T. (2011): Conflicting claims and equilibrium adjustment processes in a stock-flow consistent macro model, in: Review of Political Economy, 23(2), 189-211.

Davidson, P. (2010): Making dollars and sense of the U.S. government debt, in: Journal of Post Keynesian Economics, 32(4), 661-665.

DeLong, J.B., Summers, L. (2012): Fiscal policy in a depressed economy, in: Brookings Papers on Economic Activity, Spring, 233-274.

Diamond, P.A. (1965): National debt in a neoclassical growth model, in: American Economic Review, 55(5), 1126-1150.

Dutt, A.K. (1997): Equilibrium, path dependence and hysteresis in post-Keynesian models, in: Arestis, P., Palma, G., Sawyer, M. (eds), Markets, Unemployment and Economic Policy: Essays in Honour of Geoff Harcourt, London: Routledge, 238-253.

Elmendorf, D., Mankiw, N.G. (1999): Government debt, in: Taylor, J.B., Woodford, M. (eds), Handbook of Macroeconomics, Vol. 1C, Amsterdam: North-Holland, 1615-1669.

Engen, E.M., Hubbard, R.G. (2005): Federal government debts and interest rates, in: Gertler, M., Rogoff, K. (eds), NBER Macroeconomics Annual 2004, vol. 19, Cambridge and London: MIT Press, 83-160.

Flaschel, P., Skott, P. (2006): Steindlian models of growth and stagnation, in: Metroeconomica, 57(3), 303-338.

Franke, R. (2015): Can monetary policy tame Harrodian instability?, Mimeo, University of Kiel.

Godley, W. (1999): Seven unsustainable processes: strategic analysis, January, Levy Economics Institute, URL: http://www.levyinstitute.org/publications/seven-unsustainable-processes.

Godley, W., Lavoie, M. (2007): Fiscal policy in a stock-flow consistent (SFC) model, in: Journal of Post Keynesian Economics, 30(1), 79-100.

Hein, E., Lavoie, M., van Treeck, T. (2012): Harrodian instability and the 'normal rate' of capacity utilization in Kaleckian models of distribution and growth: a survey, in: Metroeconomica, 63(1), 139-169.

Herndon, T., Ash, M., Pollin, R. (2014): Does high public debt consistently stifle economic growth? A critique of Reinhart and Rogoff, in: Cambridge Journal of Economics, 38(2), 257-279.

Keynes, J.M. (1936): The General Theory of Employment, Interest and Money, London: Macmillan.

Krugman, P. (1998): It's baaack: Japan's slump and the return of the liquidity trap, in: Brookings Papers on Economic Activity, 29(2), 137-206.

Krugman, P. (2010): Notes on Rogoff, in: The New York Times, URL: http://krugman.blogs. nytimes.com/2010/07/21/notes-on-rogoff-wonkish/.

Krugman, P. (2013): The Japan story, in: The New York Times URL: http://krugman.blogs.nytimes. com/2013/02/05/the-japan-story/?_r $=0$.

Lavoie, M. (1995): The Kaleckian model of growth and distribution and its neo-Ricardian and neoMarxian critiques, in: Cambridge Journal of Economics, 19(6), 789-818.

Leão, P. (2013): The effect of government spending on the debt-to-GDP ratio: some Keynesian arithmetic, in: Metroeconomica, 64(3), 448-465.

Lerner, A.P. (1943): Functional finance and the federal debt, in: Social Research, 10(1), 38-51.

Nakatani, T., Skott, P. (2007): Japanese growth and stagnation: a Keynesian perspective, in: Structural Change and Economic Dynamics, 18(3), 306-332.

Nersisyan, Y., Wray, L.R. (2010): Deficit hysteria redux? Why we should stop worrying about U.S. government deficits, Public Policy Brief, no 111, Levy Economics Institute of Bard College.

Obstfeld, M. (2013): On keeping your powder dry: fiscal foundations of financial and price stability, Working paper 9563, CEPR.

OECD (2015): Economic Surveys - Japan April 2015, OECD.

Palley, T. (2002): Economic contradictions coming home to roost? Does the U.S. economy face a longterm aggregate demand generation problem?, in: Journal of Post Keynesian Economics, 25(1), 9-32.

Palley, T. (2010): The simple macroeconomics of fiscal austerity, public sector debt and deflation, IMK Working Paper, no 8/2010, Dusseldorf.

Reinhart, C.M., Rogoff, K.S. (2010): Growth in a time of debt, in: American Economic Review Papers and Proceedings, 100(May), 573-578. 
Robinson, J. (1974): History versus equilibrium, in: Thames Papers in Political Economy, Autumn.

Ryoo, S., Skott, P. (2013): Public debt and full employment in a stock-flow consistent model of a corporate economy, in: Journal of Post Keynesian Economics, 35(4), 511-527.

Ryoo, S., Skott, P. (2015): Fiscal and monetary policy rules in an unstable economy, Working paper 2015-15, University of Massachusetts Amherst. (Revised version forthcoming in Metroeconomica, doi: $10.1111 /$ meca.12139.)

Schlicht, E. (2006): Public debt as private wealth: some equilibrium considerations, in: Metroeconomica, 57(4), 494-520.

Skott, P. (1989): Conflict and Effective Demand in Economic Growth, Cambridge, UK: Cambridge University Press.

Skott, P. (2001): Demand policy in the long run, in: Arestis, P., Desai, M., Dow, S. (eds), Money, Macroeconomics and Keynes, New York: Routledge, 124-139.

Skott, P. (2012): Theoretical and empirical shortcomings of the Kaleckian investment function, in: Metroeconomica, 63, 109-138.

Skott, P. (2014): Pluralism, the Lucas critique, and the integration of macroeconomics and microeconomics, in: Review of Political Economy, 26(4), 503-515.

Skott, P. (2016): Public debt, secular stagnation and functional finance, in: Madsen, M.O., Olesen, F. (eds), Macroeconomics After the Financial Crisis: A Post-Keynesian Perspective, London: Routledge.

Skott, P., Davis, L. (2013): Distributional biases in the analysis of climate change, in: Ecological Economics, 85, 188-197.

Skott, P., Ryoo, S. (2014): Public debt in an OLG model with imperfect competition: long-run effects of austerity programs and changes in the growth rate, in: BE Press Journal of Macroeconomics, 14(1), 533-552.

Skott, P., Ryoo, S. (2015): Functional finance and intergenerational distribution in a Keynesian OLG model, Working paper 2015-13, University of Massachusetts Amherst. (Forthcoming in Review of Keynesian Economics.)

Skott, P., Zipperer, B. (2012): An empirical evaluation of three post-Keynesian models, in: Intervention: European Journal of Economics and Economic Policies, 9(2), 277-308.

Summers, L.H (2013): Presentation at the IMF Fourteenth Annual Research Conference in Honor of Stanley Fischer, URL: http://larrysummers.com/imf-fourteenth-annual-research-conferencein-honor-of-stanley-fischer/.

Summers, L.H. (2015a): Demand side secular stagnation, in: American Economic Review: Papers and Proceedings, 105(5), 60-65.

Summers, L.H. (2015b): On secular stagnation: a response to Bernanke, URL: http://larrysummers. com/2015/04/01/on-secular-stagnation-a-response-to-bernanke/.

Woodford, M. (2003): Interest and Prices: Foundations of a Theory of Monetary Policy, Princeton, NJ: Princeton University Press.

Wray, R. (2000): Can the expansion be sustained? A Minskian view, Levy Institute Policy Note 2000/5.

\section{APPENDIX 1: STABILITY OF THE DEBT RATIO}

The consumption-capital ratio is given by

$$
\frac{C}{K}=c\left(\sigma+r b-\frac{T}{K}\right)+\mu(1+b),
$$

and in steady growth with full employment we have

$$
\frac{C}{K}=\sigma-\gamma-(n+\delta) \text {. }
$$

Putting these two equations together, the required tax ratio can be written as:

$$
\frac{T}{K}=\sigma+r b-\frac{1}{c}[\mu(1+b)+\gamma+n+\delta-\sigma] .
$$


Plugging this tax ratio into the dynamic equation for the debt ratio, we get

$$
\begin{aligned}
\dot{b} & =b(\hat{B}-n) \\
& =b \frac{r B+G-T}{B}-n b \\
& =(r-n) b+\gamma-\left\{\sigma+r b-\frac{1}{c}[\mu(1+b)+\gamma+n+\delta-\sigma]\right\} \\
& =\frac{1}{c}[(1-c)(\sigma-\gamma)-\mu-n-\delta]-\left(n+\frac{\mu}{c}\right) b .
\end{aligned}
$$

The coefficient on $b$ on the right-hand side of (12) is unambiguously negative and it follows that

$$
b \rightarrow b^{*}=\frac{(1-c)(\sigma-\gamma)-\mu-n-\delta}{n c+\mu} .
$$

\section{APPENDIX 2: CORRELATION BETWEEN THE LONG-RUN VALUES OF THE} DEBT RATIO AND THE TAX RATE

Assume that all income is taxed at the same rate $t$. Then,

$$
\frac{T}{K}=t(\sigma+r b)
$$

A stationary debt ratio requires that

$$
\dot{b}=(r-n) b+\gamma-\frac{T}{K}=0 .
$$

Combining this condition with equation (15), we get

$$
(r-n) b+\gamma-t(\sigma+r b)=0
$$

and, using (14), the long-run solution for the tax rate can be written as:

$$
t^{*}=\frac{n(\sigma-\gamma-\mu-n-\delta)+\mu(\sigma-\gamma)}{r(\sigma-\gamma-\mu-n-\delta)+\sigma(\mu+c n)-r c(\sigma-\gamma)} .
$$

Both $b^{*}$ and $t^{*}$ are functions of $(c, \mu, \gamma, \sigma, n, \delta)$. Consider an increase in the marginal rate of consumption out of disposable income or wealth (an increase in $c$ or $\mu$ ). The debt ratio $b^{*}$ will fall (use (14)), but the effect on $t^{*}$ is ambiguous. Total differentiation of (17) gives

$$
\frac{d t}{d b}=\frac{r(1-t)-n}{\sigma+r b}
$$

From (17) it also follows that

$$
\frac{b}{\sigma}[r(1-t)-n]=\left(t-\frac{\gamma}{\sigma}\right) .
$$


188 European Journal of Economics and Economic Policies: Intervention, Vol. 13 No. 2

Hence,

$$
\begin{gathered}
r\left(1-\frac{\gamma}{\sigma}\right)-n=r(1-t)-n+r\left(t-\frac{\gamma}{\sigma}\right) \\
=[r(1-t)-n]\left(1+r \frac{b}{\sigma}\right) .
\end{gathered}
$$

Combining (18) and (19), the reduced-form correlation between $t$ and $b$ following a change in $c$ or $\mu$ can be written as:

$$
\frac{d t}{d b}=\frac{r(\sigma-\gamma)-n}{(\sigma+r b)^{2}} .
$$

Thus, variations in the consumption parameters lead to a negative correlation between the debt ratio and the tax rate if $r(\sigma-\gamma)<n$. 